Богдан Косановић

Универзитет у Новом Саду

Филозофски факултет

Одсек за славистику

kosanovic@neobee.net
УДК 821.161.1.09"19":314.743(=161.1)(497.1)

https://doi.org/10.18485/slavistika.2020.24.1.5

Оригинални научни рад примљено 11.02.2020.

прихваћено за штампу 21.05.2020.

\title{
СТВАРАЛАШТВО ЛЕОНИДА ЛЕОНОВА У КРИТИЦИ РУСКЕ ЕМИГРАЦИЈЕ У КРАЉЕВИНИ СХС/ЈУГОСЛАВИЈИ
}

Ово истраживање је посвећено рецепцији стваралаштва руског класика Леонида Леонова (1899-1994) од стране руске емиграције у Југославији - између два светска рата. Њиме желимо обележити стодвадесетогодишњицу пишчевог рођења.

Са 37 критичких прилога Леонов је у раздобљу између два рата био најпопуларнији совјетски писац у Југославији. Географија текстова о њему била је разноврсна, баш као и компетенција њихових аутора (Слоним, Митропан, Струве, Јелачић, Голенишчев-Кутузов, Тарановски и др.). Руски емигранти су утрли пут српским и хрватским посленицима - ка даљем плодном промишљању дела овог писца, њиховом превођењу.

Кључне речи: Леонид Леонов, руска емиграција, рецепција.

This paper is dedicated to an examination of the reception of the works of Russian classic Leonid Leonov (1899-1994) by critics of Russian extraction living in Yugoslavia between two world wars, one hundred and twenty years after the writer's birth.

With 37 critical articles dedicated to his work, Leonov was the most popular Soviet writer in Yugoslavia. The landscape of the articles dedicated to him was diverse, just like the competences of their authors (Slonim, Mitropan, Struve, Jelačić, Goleniscev-Kutuzov, Taranovsky etc.). Russian emigrants opened the path for Serbian and Croatian authors to further consider the works of the writer.

Keywords: Leonid Leonov, Russian emigration, reception.

У глобалним друштвено-историјским околностима краја XX и почетка XXI века приметно расте интересовање да се дубље расветле, осмисле и проуче некадашње велике сеобе, насилне миграције народа, настале као последица великих ратова и револуција. Из сасвим разумљивих разлога посебно интересовање међу емигрантолозима влада за тзв. први талас руске емиграције. Ако се узме у обзир литературоцентричност културе датог периода, онда неће бити случајно што се, по правилу, у истраживањима посебна пажња посвећује раније из идеолошких разлога проскрибованим проблемима рецепције руске културе совјетског периода у руској емиграцији. У том смислу се да запазити да се у последње време појављују зборници, монографије општег карактера, баш као и прегледни чланци и посебна истраживања, посвећени пријему стваралаштва појединих руских писаца, пре свега „великих класика“, нешто мање и совјетских. У овом смислу карактеристично је да у иначе квантитативно богатој леоновијани сама рецепција стваралаштва овог изузетног писца од стране руских емиграната спада међу најмање изучене теме. Да се овде позовемо само на два илустративна примера. У најкомпетентнијој историји руске емигрантске књижевности Глеба Струвеа нема ширег, а поготово не и дубљег погледа на критичке текстове - за рачун белетристике и журналистике (Струве 1996). Досад најпосвећенији овој теми информативни чланак Н. 
В. Сорокине (Сорокина 2005) је у суштини само приступ датој проблематици. Тамо прикупљени материјал је некомплетан, по правилу није документован изворима из периодике, већ је претежно дат „из друге руке“ - користећи се прештампавањима, изводима из нових антологија, што ће рећи већ селектованим материјалима. Очигледно, да би се створио прави увид у пријем Леонова у емиграцији ваља га најпре проучити одвојено, по појединим центрима.

У овом нашем чланку бавимо се емигрантском рецепцијом Леонова у Југославији. (На тему руске емигрантске књижевности и публицитике у Србији вид. наш прегледни чланак Косанович 2008). Треба приметити да је дата тема само делимично дотицана у прегледним истраживањима југословенских русиста (вид. Бабович 1969; Станишич 1987; Копривица 1999), тако да ни приближно није по заслузи исцрпљена. Напротив, сматрамо да тема захтева целовитију анализу, заслужује посебан приступ - са комплетираним материјалом, посебно оним из дневних листова. Такође су јаки разлози да се теми приђе алтеритетно, са тачке гледишта одраза новијих, драстично измењених идеолошких и политичких погледа на одговарајућу епоху.Притом нам се намећу као основни методи компаративно-рецептивни и аналитички.

Међуратни период међусобних веза између Русије/СССР и Србије/Краљевине Срба, Хрвата и Словенаца (убрзо преименоване у Југославију) протицао je у нагло измењеним историјским околностима, упамћеним по великим, драматичним идеолошким променама - у контексту европске и светске политике као такве. СССР је постао прва у свету земља социјализма, док је Југославија била монархија - истурена представница ,заштитног кордона“ (Cordonsanitaire) против „бољшевичке опасности“. Отуда је карактеристично да су дипломатски односи између две блиске словенске земље били прекинути све до преговора у јуну 1940. године, чији је крајњи резултат био Споразум о пријатељству и ненападању, закључен 5. априла 1941. године, дакле само дан пре фашистичког бомбардовања Београда. У међувремену је југословенска влада свесрдно подржавала своју руску емиграцију, коју је чинило око 45000 људи. Из свега овога проистиче да су вековима одржаване и неговане културне везе биле напрасно прекинуте. О било каквој директној вези и културној размени у таквим условима није могло бити никакве речи. Комуникација је остваривана посредно, највише путем личних контаката у иностранству. Притом су комунисти били извесни изузетак, мада су, као што је познато од краја 1920. године, били у илегали и одржавали везу са Коминтерном. Када се све ово има у виду, онда је јасно зашто су путеви информација о догађајима у СССР водили преко Западне Европе, пре свега преко Француске и Немачке, понекад и Чехословачке. При томе је глава улога у упознавању народа Југославије са дешавањима у култури прве земље социјализма припала управо руској дијаспори.

Ово су били општи услови у којима се одвијало упознавање југословенске, а пре свега српске, културне јавности са делима „нове руске литературе“, дакле и Леоновљевим. Општепознато је да је Леонид Максимович Леонов рано, већ средином 20-тих година прошлог века, у суштини будући још писцем-почетником, постао познат страним читаоцима. У том смислу ни Југославија није била изузетак. У њој се први пут име овог совјетског писца појавило у штампи 1924. године у једном информативном чланку, у загребачком часопису „Вијенац“, 
под насловом „Неколико ријечи о данашњој руској књижевности““. Аутор чланка се потписао као Николај Рошчин, што је у ствари псеудоним Николаја Јаковљевича (према неким изворима Ивановича) Фјодорова (Николай Яковлевич Федоров, 1892-1980), у то време познатог књижевног критичара, преводиоца, емигрантолога и позоришног делатника. Рошчин је међу савременим младим руским писцима издвојио Леонида Леонова, јер он транспонује „оно велико чувство одговорности и мјере, оно озбиљно и дубоко приближење к животу“, које допушта уверење да ће писац постати достојни настављач стваралаштва Пушкина, Достојевског, Гогоља и Толстоја. Занимљиво је да се још тада, 1924. године, Рошчин (Фјодоров) заложио да се руска књижевност разматра ,јединствена, цијеловита, нераздробива на совјетску и емигрантску“ (Roščin: 558).

Године 1926. у „Српском књижевном гласнику“ штампана је компилација чланка познатог француског писца-академика (узгред речено, рођеног у породици руског лекара) - Жозефа Кесела (Joseph Kessel, 1898-1979). Чланак је посвећен стању у „Новој руској литератури“. У својој компилацији српски критичар и преводилац Светислав Петровић је пренео главне акценте овог текстаиз „Париске ревије“ („Revue de Paris“). Кесел се најпре задржава на совјетској поезији, поименице издвајајући Пастернака, Мајаковског и Јесењина, да би потом међу прозним писцима истакао у првом реду Пиљњака, Всеволода Иванова и Леонова, као представнике „источне линије“, а Иљу Еренбурга и Исака Бабеља као ,западњаке“. При томе, француски писац се веома похвално изразио о Леонову, истичући да је без обзира на даровитост Иванова „таленат Леонова можда још и већи“. Кесел је већ у раном стваралаштву Леонова запазио његове главне карактеристике: пре свега умеће промишљања суштине руског националног карактера. Леонова је овај француски писац оценио као „најрускијег од младих руских писаца“, налазећи да „он храни своја дела искључиво сељачким и револуционарним фолклором“. Својом склоношћу ка стилизацији, својим колоритним и прецизним језиком, најзад и пејзажном декоративношћу, Леонов га подсећа на Јесењина (Петровић 1926: 610-611).

После овог чланка убрзо се, такође у „Српском књижевном гласнику“, појавио нови преглед совјетске књижевности, у којем је пажња посвећена и Леонову, са тежиштем на анализу његовог првог романа. У информативном чланку Марка Слонима, насловљеном „Руска књижевност за време револуције“, истакнута је теза да су „најизразитији представници читаве ове руске књижевности без сумње Замјатин и Леонов“, док Пиљњаку смета његова неуравнотежена природа и маниризам (Слоним 1927: 507). Слоним даје предност Леонову као аутору „заиста најбољег приказа руске револуције“", пре свега руског села - у роману „Јазавци“. Критичар презицира: „То је без сумње највеће дело које се појавило у руској књижевности последњег деценија“ (стр. 507). Даље је изложена сижејнофабуларна потка романа. Слоним налази да је роман „Јазавци“ структуиран првенствено у реалистичком тону, али са примесом романтизма. Он посебно хвали психолошке мотивације Леонова. По његовом мишљењу стваралаштво Леонова је очигледан пример како се „у делима младих руских писаца не може више наћи романтичног месијанизма и религиозних надања првог периода руске револуције“. Интересантно је да емигрантски критичар није оптерећен 
идеолошким предрасудама. Према његовом мишљењу из дела Леонова и њему сличних писаца, који су тек почели да се баве књижевношћу, одише „здравим и бодрим изграђивањем снага, (...) вером у будуће руско сељаштво“ (стр. 509).

Имајући у виду дуготрајно, продуктивно интересовање Марка Љвовича Слонима (1894-1976) за Леоновљево стваралаштво, сада ћемо се присетити основних биографских података о овом истакнутом емигрантском критичару. Он је филолошко образовање стекао на Петроградском универзитету. У емиграцији се сељакао по многим земљама, мењао места боравка (Фиренца, Праг, Париз, Њујорк, Женева, Ница). Често је боравио и у Југославији. Као политички активиста прво је припадао есерима, а у емиграцији увек заузимао либерално-демократске позиције, учествујући у различитим групацијама и кружоцима. Одликовала га је свестраност: бавио се публицистиком, есејистиком, књижевном и научном критиком, превођењем... Будући полиглота, писао је на неколико језика. Као публициста и књижевни критичар у дијаспори је уређивао многе часописе. За нашу тему је од значаја да је у емиграцији објавио велики број чланака и неколико књига из области руске књижевности. Слоним је био стални сарадник најзначајнијих органа руске емиграције у Београду - „Руског архива“ (1928-1937), гласила у коме су стални сарадници, између осталих, били и писци - Цветајева, Замјатин, Ремизов, критичари - Лапшин, Љацки, Штејн и др., да и не говоримо о познатим позоришним критичарима, историчарима, социолозима, економистима и публицистима. Часопис је био веома на цени код српских интелектуалаца, излазио је на српском језику, на који су текстови превођени са руског (познати преводиоци: Г. Крклец, М. Пешић и др.), што је благотворно утицало на преплитање српске културе са руском, а тако посредно и са западноевропском, тј. светском културом као таквом.

Дакле, 1928. године у овом гласилу „за политику, културу и економију Русије“ појавио се нови панорамски чланак Слонима: „Струје савремене руске литературе“. У њему је аутор покушао да систематизује главне тематске и стилске тенденције савремених совјетских писаца. Његов тадашњи избор занимљивих и несумњиво даровитих писаца валидан је и са данашње тачке гледишта. „Поред Замјатина, Бабеља, А. Толстоја, Ремизова, А. Белог и донекле Зошченка, у прве редове савремене књижевности треба поставити Л. Леонова, К. Феђина, М. Булгакова и Б. Пиљњака“. Коментаришући стваралаштво двадесетосмогодишњег Леонова, критичар и овај пут полаже у њега велике наде. Трудећи се да га смести у књижевноисторијски контекст, Слоним изводи паралеле са стилом Замјатина, Пиљњака, А. Белог. А у управо изашлом „Лопову“ исправноналази сродност са психологизмом Достојевског (Слоним 1928: 152). Узгред, било је то прво упознавање југословенских читалаца са романом „Лопов“.

Интересовање усредсређено на стваралаштво руских писацапосле револуције резултирало је осликавањем њиховим кратких књижевних портрета (обимом око пола штампаног табака). Из ове серије је већ 1929. године у „Руском архиву“ изашао чланак „Леонид Леонов“ (Слоним 1929: 162-170). Исти тај текст је заједно са тринаест других портрета ушао у књигу „Портрети савремених руских писаца“ (на српском Београд, 1931; у Паризу изашла у скраћеном за три поглавља облику, на руском, 1933. године - као „Портреты советских писате- 
лей“"). Овде Слоним, као увод у разговор о Леонову, даје општу карактеристику руске класичне књижевности, истичући да се она у великој мери разликује од западноевропских књижевности - озбиљним расправљањем философских, моралних и психолошких проблема, промишљањем „уклетих питања“ (стр. 162). Животворно струјање те велике књижевности критичар налази у стваралаштву Леонова и Феђина. Без икакве дилеме Слоним поставља Леонова на пиједестал најбољег послереволуционарног младог писца. Он се придржава својих ранијих исказа о утицају савременика на Леонова, сматрајући да је у даљем развоју писца све те упливе прекрио психологизам Достојевског, мада то и не смета његовој самобитној приповедачкој техници. Критичар аргументује своје ставове анализом таквих дела као што су: „Ковјакинови записи“, „Крај ситног човека“, „Петушихински пробој“, „Јазавци“, „Лопов“, драма „Унтиловск“, и тек изашле „Необичне приче о сељацима“. У после револуције појачаном актуелном философском споруо смисаоним кодовима категорија колективизма и индивидуализмa и њиховом практичном значају, Леонов се приклања њиховој хуманистичкој узајамној хармонији, при чему ,јавно гласа за људску индивидуалност“, - сматра Слоним (стр. 170). Интересантно је да Десимир Благојевић, српски рецензент Слонимове књиге, мада ју је оценио веома позитивно, ипак аутору упућује замерку поводом његовог третмана „најрускијег писца данашњице“, сматрајући да он „није довољно нагласио сву ону трагичну луталачку упућеност Леонида Леонова да пронађе последња, проклета питања“ која се срећу код Толстоја и Достојевског (Благојевић: 5).

У међуратном периоду Слоним је и даље у својим прегледним чланцима посвећеним совјетској књижевности износио своје мишљење о стваралаштву Леонида Леонова. (Сада већ прихватајући управо тај појам „совјетска“). Тако је у чланку „Нова дела совјетске књижевности“ анализирао роман „Соћ“, смештајући га у контекст са романима Гладкова, Каравајеве и Шагињан. Не поричући идеолошку тенденциозност „Соће“, Слоним ју је сматрао првим успешним покушајем остварења „производног романа“, кога је уз то, што је парадоксално, остварио „сапутник“, представник „психолошке школе“ (Слоним 1930: 171). Критичар подвлачи спационирано: „Леонов је показао, да занос изграђивања, тежња да се створи нова Русија јесте општенародно, а не само бољшевичко дело“ (стр. 173). У таквом тумачењу препознајемо мисао о томе да се већ у самом приказивању револуционарног волунтаризма и рационалности традиције крије покушај превладавања доминирајућих стереотипа поруџбина производног романа.

Следећи чланак Слонима - „Шта се дешава у совјетској литератури“ изашао је у „Руском архиву“ 1933 . године. У њему се као књижевна новост кратко коментарише роман „Скутаревски“ (Слоним 1933: 92, 95).

У облику књижевних портрета изражавао се и Петар Андрејевић Митропан (1891-1988), предавач Универзитета у Скопљу. Он је 1929. године у загребачком часопису „Нова Европа“ објавио чланаксугестивног наслова „Наследник Достојевскога - Леонид Леонов“ (Митропан 1929: 155-160). Ауторов првенствени циљ је био да упозна југословенске читаоце са стваралаштвом Леонова, сматрајући даје оно дотад првенствено било познато и признато међу руским емигрантима. Реч је о најкрупнијем представнику књижевности совјетске 
Русије, - оцењује Митропан. Он излаже занимљиву тезу да ће се у личности Леонова „спојити (и формално, тематски и психолошки) обе струје руске литературе: емигрантска и тзв. совјетска (релативан, случајан и пролазан појам)“ - sic! - Б. К. (стр. 156). То ће рећи да је, упоредо са већ поменутим Рошчином (Фјодоровом), Митропан на више од пола века антиципирао процесе у култури савремене руске перестројке. Овде још треба рећи да је дати Митропанов текст послужио као основа за предговор првом српском преводу “Лопова", где је он поновио своју тезу да је Леонов “заставник младог покољења савремених руских писаца".

Своју дубоку и садржајну анализу поетике Леонида Леонова Митропан је углавном базирао на формално-садржинској анализи “Лопова", тврдећи да је његов аутор “пошао трагом великог учитеља - Достојевског” (стр. 157). Међутим, критичар замера Леонову на његовој “склоности ка патетичном тону” (стр. 160).

Леоновом се у Србији рано заинтересовао и Евгеније Захаров (псеудоним, право име Лев Горович Захаров, 1903-1975; публициста, књижевни критичар и преводилац). У својим многобројним чланцима и новинским белешкама овај плодотворни посленик је континуирано пажљиво пратио стваралаштво Леонова. Започео је са освртом на роман „Соћ“, у целини га оценивши веома негативно. Пошто се задржао на „случајевима“ (гоњењима) Замјатина и Пилњака, Захаров је прешао на Леоновљеву биографију, истакавши да је реч о талентованом писцу, који је био приморан да се приклони пропагандној бољшевичкој тенденциозности. Отуда је његов нови роман „сав поруџбина, сав пропаганда“, „брошура у облику романа“ (Захаров 1930: 4).

У прегледу главних догађаја у руској књижевности 1930. године, објављеном у најстаријем српском књижевном часопису „Летопис Матице српске“, Захаров саопштава о изласку из штампе новог романа „веома талентованог Леонида Леонова“, обликованог према социјалној поруџбини. (Очигледно је поново реч о „Соћи“, мада то није прецизирано). Упоредо са Леоновом наведена су и имена Сирина (Набокова), Гајто Газданова, Нине Берберове и др. (Захаров 1931: $96,106)$.

После ове уследила је нова, непрентенциозна белешка Захарова о актуелним догађајима међу совјетским писцима, у којој се на првом месту говори о Леонову. Захаров ту критикује додворавање аутора „Соће“ (тенденцију совјетске пропаганде) и хвали роман „Лопов“ (Захаров 1931a: 107). И у свом следећем прилогу о новостима у руској књижевности овај критичар доследно изражава своје мишљење о постојању два руска различита табора, међусобно „духовно зараћена света“, дакле и две књижевности - совјетске и емигрантске. Када сведочи о талентованим совјетским писцима, он на прво место поставља Леонова (Захаров 1931б: 31). Карактеристично је да и свој кратки новински приказ париског часописа „Бројеви“ („Числа“) овај критичар завршава указивањем на у њему објављене солидне приказе нових дела Леонова и Ољеше (Захаров 1932: 7). Ово наводимо не само као пример надвладавања размимоилажења између критике у СССР и дијаспори, већ и као доказ да је емиграција редовно показивала интересовање за актуелне догађаје у културном животу Отаџбине. 
У серији мањих чланака-бележака овог критичара и надаље се среће име Леонида Леонова. У следећа два критичка текста као црвена нит се провлачи супротстављање Леонова Гладкову, његовом извештаченом патосу. О томе је Захаров изнео своје мишљење најпре поводом изласка српско-хрватског превода романа „Цемент“ (Захаров 1931в: 6) и романа Тињанова (Захаров 1931г: 6).

Исте те, 1931. године, у београдском листу „Правда“ Захаров коментарише анкету коју је спровео париски емигрантски „Нови лист“ („Новая газета“), са питањем: Које руско књижевно дело, написано за последюих пет година, сматрате најзначајнијим и најинтересантнијим? Захаров издваја одговоре Б. Сосинског и А. Ладинског, који су, између осталих, гласали за Леонова („Соћ“ и ,Лопов“") (Захаров 1931д: 17).

Као хроничар културног живота у СССР, Захаров је обратио пажњу српске културне јавности на статистичке податке о најчитанијим писцима Совјетске Русије. Међу класицима најчитанији су били Толстој и Горки, међу новим писцима - на првом месту Шолохов, а после њега и Леонов, упоредо са Памфјоровом, Гладковом и Серафимовичем. Занимљиво ће бити да је управо због Леонова руски емигрантски критичар посумњао у осећање уметничког укуса совјетских читалаца, кад се узме у обзир да они дела Леонида Леонова ,једног од најдаровитијих писаца читају мање од неталентованог Глаткова“" (Захаров 1934: 10). Пристрасност према Леонову показао је Захаров и у приказу Тихоновљевог коментара Резолуције ЦК КП СССР О реформи књижевноуметничких организаџија, кад се Тихонов критички осврнуо на Леоновљев роман „Скутаревски“, у коме се, по његовом мишљењу „уместо решења великог дела“ само назиру „његове делимичне геометријске контуре“ (Захаров 1933: 8).

Поштујући хронологију, до сада смо се потрудили да узмемо у обзир најбитније критичке текстове који сведоче о рецепцији Леонова од стране руских емиграната у Југославији. Као што смо се могли уверити њих има подоста. Међутим, библиографски списак показује да они чине само део јединица које смо сакупили. По себи се разуме да су критички текстови различити по свом основном карактеру, обиму, дубини интерпретације, замислима, задацима и циљевима, те дакако и квалитетима. Сада ћемо укратко прокоментарисати и друге, релативно мање радове, без којих се, свакако, не може представити потпуна рецепција Леонида Леонова.

Кренућемо од чланка познатог загребачког критичара Константина Константиновића Римарића-Волинског (право презиме Рејмерс) 1988-1946 - „Четири писца: Зошћенко - Еренбург - Пиљњак - Леонов. Европа и Русија - село и град“. Главни предмет његове анализе садржан је у поднаслову: разматрање опозиције село/град у делима четири наведена совјетска писца. Однос Леонова према овој проблематици показан је на примеру романа „Јазавци“, у ствари је илустрован путем критичаровог развученог, подробног препричавања, уз навођење његових оцена од стране појединих емигрантских аутора. На крају Римарић-Волински закључује да Леонов поставља „антитезу града и села и рјешава је компромисно“, мада је у том смислу уметничко-философско преимућство ипак на страни Пиљњака. Критичар посебно вредном сматра чињеницу да се у лицу ова два писца огледа „повратак к етичком схватању проблема живота“ и то у епоси „култа силе“ (Rimarić-Volinski 1932: 85). 
Ирина Кунина-Александер (1900-2002) - позната списатељица и књижевни критичар је у међуратном периоду боравила и у Загребу, где је у периодици објављивала књижевнокритичке чланке. Највреднијим међу њима може се сматрати њен преглед „Руске књижевности иза револуције”, из кога за ову прилику издвајамо сегмент посвећен Леониду Леонову. Он садржи основне чињенице о његовим делима, почев од “Погибије Јегорушке" и завршно са “Лоповом". Из приповедачке технике Леонова Кунина издваја као најкарактеристичније уметничке поступке сказ и стилизацију. И она се бави “етапама развоја" и "доказа уметничког напредовања” младог писца (Aleksander 1928: 339-340), тако да то већ сада можемо назвати општим местом прилога југословенских критичараемиграната о Леонову.

Вреди се позвати на други текст већ на почетку овог чланка поменутог загребачког хроничара совјетског књижевног живота - Николаја Ивановича Федорова (1892-1980). (Своје презиме је код нас писао баш тако: Федоров - Б. К.). У његовом прегледу „Путови стварања нове руске књижевности“ посебно поглавље посвећено је совјетској прози. Федоровљев закључак да је совјетска књижевност уздуж и попреко прожета „најразличитијим врстама злочина“ је, засигурно, веома спорно (Fedorov 1940: 356). Додуше, ваља имати у виду да се Федоров и ограђује: у овом смислу утешно делује Леонов. Као верни следбеник Достојевског, он је наследио његову етику и продуховљени психологизам, па самим тим враћа совјетску књижевност њеним класичним националним изворима (стр.358). Исто тако је занимљиво да се и дописник београдског „Руског архива“ из Прага - Надежда Федоровна Мељникова-Папоушкова (1891-1978) у свом дискурсу о „Старој и новој руској интелигенцији“ обилно позива на текст Леоновљевог „Краја ситног човека“ (Мељникова-Папоушкова 1928: 114-115).

Редакција „Руског архива“ је доиста пажљиво пратила књижевне новости, па је стога често публиковала понекад и ситне вести, а да се и не говори и о приказима часописа и књижевноуметничких дела. А у њима је врло често, у овој или у оној мери, било присутно и име Леонида Леонова, што је увелико доприносило познавању овог писца и његовој репутацији. Тако, на пример, сачинивши преглед „Совјетских часописа у 1928. години“, Б. Аратов (псеудоним Марка Слонима - Б.К.) саопштава да је у московском „Новом свету“ („Новый мир“) објављена „Провинцијска прича“, у којој писац наставља „пут романтичног психологизма“, започет у „Лопову“. Затим је реч и о „Унтиловску“, штампаном у истом совјетском периодику (Аратов 1928: 114, 115).

Следеће године писац Бронислав (Владимир) Александрович Сосински (1900-1987) сведочи о књижевној вечери у Паризу, посвећеној Леонову, у организацији емигрантске омладинске групе „Кочевје“ („Кочевье“). Он потврђује да је публика одушевљено прихватила стваралаштво Леонова, посебно приповетку „Повратак Копиљова“ на чијој се анализи и задржава (Сосински 1929: 160-163).

И у трећој деценији прошлог века, часопис „Српски књижевни гласник“ се трудио да не заостане у праћењу књижевних догађаја у Совјетском Савезу. У том циљу, на пример, објављен је и кратки напис о изласку у Москви посебног издања романа „Скутаревски“. Аутор овог прилога био је Алексеј Кирилович 
Јелачић (1892-1941), међу руским емигрантима познати историчар и педагог (Јелачић 1935: 77). Вид. проширени приказ истог овог аутора у „Руском архиву“ (Јелачић 1935а: 203-206).

Само неколико месеци доцније часопис „Српски књижевни гласник“ објавио је прегледни чланак Глеба Петровича Струвеа (1898-1985) - тада младог слависте и историчара, који ће постати знаменити емигрантолог. Чланак је носио наслов „Књижевност у савременој Русији“ и, лако је претпоставити, позивао се и на Леонова, конкретно на, по мишљењу Струвеа, занимьиве романе „Јазавци“, „Соћ“ и „Скутаревски“ (Струве 1935: 624, 625).

Овај панорамски преглед рецепције Леонова био би непотпун без макар и невеликог прилога датој проблематици још једног познатог научника - Илије Николајевича Голенишчева-Кутузова (1904-1969) - песника и преводиоца који ће постати компаратиста светског гласа. Он је у „Српском књижевном гласнику“ објавио приказ тек објављене књиге Глеба Струвеа „Руска совјетска књижевност“ („Русская советская литература“, Лондон 1935). Ту је аутор приказа илустровао започете процесе либерализације и толеранције почетком 20тих година на примеру Леонова, који је захваљујући новој атмосфери могао објавити „Јазавце“ и „Лопова“ (Голенишчев-Кутузов 1935: 303).

Најзад, исти аутор се испробао и у осветљењу „Послератне руске књижевности -њене еволуције у правцу индивидуализма и национализма“. Обдарен изузетним нервом за разумевање и осмишљавање поезије, Голенишчев-Кутузов се у уводном делу свог чланка најпре позива на стваралачку мисао симболиста - Блока и Белог, да би затим прешао на стање у руској прози, непосредно пре револуције. Према његовом мишљењу, формирање „Серапионове браће“ (на иницијативу Замјатина) имало је велику улогу у освајању стваралачких слобода. Сем футуриста, Јесењина, Ахматове и Волошина, несумњиву улогу у развоју нове књижевности одиграли су и тзв. сапутници - Бабељ, Вс. Иванов, а понајвише - Леонов, коме Голенишчев-Кутузов посвећује велику пажњу(на једној и по страници текста) - задржавши се на приповетци „Крај ситног човека“ и романима „Јазавци“, „Соћ“ и „Скутаревски“. Голенишчев-Кутузов завршава свој чланак очигледно у то време општеприхваћеном прогнозом: од Леонова се могу очекивати и значајнија дела, посебно сада, када се, делимично, смањује притисак поруцбина, како строго званичних, тако и сочијалних, - што су „унаказиле толика књижевна дела“ (Голенишчев-Кутузов 1938: 30).

Разумљиво, поставља се питање да ли је постојало интересовање за инсценацију Леоновљевих дела у позориштима предратне Југославије? Нажалост, о томе немамо никакве поузданије податке. Јер, зна се да је документација о емигрантском животу уопште била оскудна. Али је и то мало што је постојало изгорело је, или је уништено у току Другог светског рата, или непосредно после њега - у „идеолошким чисткама“. Засад једини трагови које смо успели пронаћи јесу сведочанства публициста Василија Глуздовског (Глуздовски 1934: 6) и глумице Јулије Ракитине (Ракитина 1934: 6) о припремама за постављање на сцену једне од многобројних београдских емигрантских позоришних група Театра руске драме - комада „Скутаревски“, који је био изазов као „трагедија руске интелектуалне породице“. Да ли је та замисао и остварена, или јој је нешто засметало - засад нам није познато. 


\section{Да закључимо.}

Прикупљени, систематизовани и интерпретирани материјал (37 критичких одјека за тринаест међуратних година) даје очигледан увид у рано, стално и квалитетно бављење руских емиграната у Југославији стваралаштвом Леонида Максимовича Леонова. Највише захваљујући емигрантским гласилима Леонов је у периоду у коме је реч био најпопуларнији млади совјетски писаи у Југославији. Приметно је да је откриће Леонова подстакло српске и хрватске критичаре да о њему пишу, преводе његова дела. Прескочивши природни редослед излагања, можемо рећи да је овим припремљена и изузетно плодна рецепција Леонова у Југославији после Другог светског рата. Овај наш преглед је показао да је упркос свему руска емиграција у Југославији будно пратила актуелни културни живот у Совјетском Савезу и уз помоћ других емигрантских центара трудила се да буде у току, да не заостаје. И није заостајала! Напротив. Леонову се у међуратној Југославији посрећило. Међу емигрантима је, углавном, имао компетентне критичаре и пажљиве читаоце.

Географија објављених текстова које смо имали у виду је доста разноврсна. Штампани су првенствено у Србији, Хрватској и Босни - на српском, ређе хрватском језику. Сем емиграната из Југославије аутори су били и дописници из других европских центара, будући да су руски емигранти одржавали добре узајамне везе и контакте. Међу њима су били не само млади књижевни критичари, који су потом израсли у изузетне филологе - М. Слоним, П. Митропан, Г. Струве, К. Римарич-Волински, А. Јелачић, И. Голенишчев-Кутузов, Е. Захаров и др., већ и мање познати критичари и публицисти. Текстови су писани на матерњем - руском језику, а у циљу објављивања превођени су на српски, ређе хрватски. Изузетак су чинили Митропан, Голенишчев-Кутузов и Захаров, који су толико овладали српским језиком, да су на њему могли слободно говорити и писати. У превођењу критичких текстова са руских рукописа посебно су се истакли горепоменути П. Митропан и познати писац Г. Крклец. Такође треба поменути да су се двојица руских емиграната веома успешно латила посла превода Леоновљевих дела на српски језик: П. Митропан је превео „Пут ка океану“, а К. Тарановски - „Скакавце“.

Емигранте је Леонову привлачило његово философско-етичко промишљање „вечитих питања“ живота, посебице руских „уклетих питања“, пореклом из традиције руске класике, баш као и продубљено уметничко осмишљавање проблема револуције и покушаја изградње „новог живота“, осликавање међуодноса града и села, интелигенције и „обичног народа“, вештина уметничког обликовања психологије књижевних јунака, као и изузетна, самобитна сликовитост језика и стила.

Руски емигранти у Југославији једнодушно су сматрали да је роман „Лопов“ најбоље Леоновљево дело. Тако га је процењивала и целокупна југословенска културна јавност. Карактеристично је да је после објављивања превода „Лопова“, код издавача „Космос“ у едицији „Ремек-дела светске књижевности“, у новинским рекламним белешкама („Политика“, „Правда“, „Време“ и др.) роман „Лопов“ рекламиран као „генијално дело једног од најјачих нових руских писаца“, „најоригиналније дело савремене светске књижевности“ (на пример, Аноним 1939а: 5; Аноним 1939б: 29). 
Чланци и цртице/белешке на које смо овде обратили пажњу углавном су објективни у идеолошком и политичком смислу. Штавише, из њих, по правилу, одише оптимизам, љубав према отаџбини и скривена жал за њом.

Критички чланци, прегледи књижевних догађања, прикази и цртице о Леонову по правилу су штампани у истакнутим периодицима у Београду („Руски архив“, „Српски књижевни гласник“, „Нова смена“, „Политика“", „Време“), Новом Саду („Летопис Матице српске“), Скопљу (,Јужни преглед“), Загребу („Нова Европа“, „Вијенац“, „Хрватска ревија“, „Хрватска смотра“), у Бањалуци („Књижевна Крајина“). Популаризацији и пријему Леоновљевог стваралаштва су исто тако доприносила и јавна предавања о њему, попут оних које су својевремено одржали на београдском Народном универзитету „Коларац“ И. Голенишчев-Кутузов 30. јануара 1936. године (Аноним 1936: 18) и Митропан 16. децембра 1939 (Аноним 1939: 17).

Поставља се питање улоге и утицаја критичких чланака и других написа о Леонову. Одговор ћемо започети констатацијом да су ови прилози понајвише имали информативну и пропагандну улогу: да обрате пажњу и упознају читаоце руске емиграције и српске културне јавности са новим, самобитним совјетским писцем. Показује се да је тај задатак успешно остварен.

Упркос свему тешко би било говорити о неком иоле комплекснијем утицају Леонова на писце у Југославији у међуратном периоду. Истина, Глеб Струве је лапидарно писао о извесном утицају на Ивањикова, при томе га убрајајући у провинцијалне руске емигрантске писце (Струве 1996: 206). (Георгиј Дмитријевич Ивањиков 1904-1968 је занимљива личност руске емиграције; он се из Чехословачке преселио у Београд, где је деловао као прозни писац и новинар, показивао изузетно интересовање за богословље, био члан неколиких књижевних удружења и идеолошких кружока у руској емиграцији, да би се за време и после рата прославио као филмски сниматељ).

Александар Флакер убраја Леонова (заједно са Еренбургом, Пиљњаком, Гладковом и Лебдинским) у писце чија је рецепција надахњивала оријентацију „социјалне књижевности“ у Југославији (Флакер 1979: 9). Са друге стране, у одјецима, интерпретацијама и оценама стваралаштва Леонова објављеним у Југославији понегде се дају приметити и трагови утицаја у то време познатог совјетског критичара А. Воронског.

Најзад, реултати до којих смо дошли у овом истраживању су у сагласју са закључцима Н. Сорокине:

„Многи ставови чланака критичара совјетске дијаспоре 20-30-тих година о стваралаштву Л. Леонова развијани су у чланцима совјетских научника, а нека запажања кртичара - емиграната својом исправношћу и независношћу превазилазе аналитичке оцене совјетских критичара“" (Сорокина 2005: 5; превод наш - Б. К.).

Уосталом, све што је досад написано о Леонову сада једнако равноправно припада историји књижевности, њеној рецепцији по непристрасним мерилима и оценама. 


\section{Цитирана литература}

Бабович, Милосав. Творчество Леонова в сербо-хорватской критике.Творчество Леонида Леонова. Ленинград: Издательство “Наука”, 1969, 366-392.

[Babovich, Milosav. Tvorchestvo Leonova v serbo-khorvatskoî kritike.Tvorchestvo Leonida Leonova. Leningrad: Izdatel'stvo "Nauka", 1969, 366-392]

Копривица, Драган. Леонид Максимович Леонов: рецепција стваралаштва на српском и хрватском језичком подручју. Подгорица: УНИРЕКС, Београд: ЈУУНИРЕКСМБ, 1999.

[Koprivica, Dragan. Leonid Maksimovič Leonov: recepcija stvaralaštva na srpskom i hrvatskom jezičkom području. Podgorica: UNIREKS, Beograd: JUUNIREKSMB, 1999]

Косанович, Богдан. «Русская эмигрантская литература и журналистика в Сербии: результаты и перспективы изучения». [В:] Русское зарубежье - духовный и культурный феномен. Сб. статей, вып. 2. М: Московская академия образования Натальи Нестеровой, 2008, 25-29.

[Kosanovich, Bogdan. «Russkaîa èmigrantskaî literatura i zhurnalistika v Serbii: rezul'taty i perspektivy izuchenīa»». [In:] Russkoe zarubezh'e -dukhovnyı̆ i kul'turnyı̌ fenomen. Sb. stateî, vyp. 2. M: Moskovskaîa akademîâ obrazovanirâ Natal'i Nesterovoř, 2008, 25-29]

Сорокина, Наталья. «Творчество Л. М. Леонова 1920-х годов в оценке критиков русского зарубежья». [В:] Вестник ТГПУ, вып. 6 (50), серия: Гуманитарные науки (филология), 2005.

[Sorokina, Natal'â. «Tvorchestvo L. M. Leonova 1920-kh godov v otsenke kritikov russkogo zarubezh'ầ». [In:] Vestnik TGPU, vyp. 6 (50), serîa: Gumanitarnye nauki (filologiîa), 2005]

Станишич, Йоле. «Леонид Леонов в Югославии». [В:] Леонид Леонов: Творческая индивидуальность и литературный процесс. Ответств. ред. В. А. Ковалев и Н. А. Грознова. Ленинград: Издательство “Наука", 1987, 277-299.

[Stanishich, Ǐle. «Leonid Leonov v TUgoslavii». [In:] Leonid Leonov: Tvorcheskââ individual'nost' i literaturnyı̌ proțess. Otvetstv. Red. V. A. Kovalev i N. A. Groznova. Leningrad: Izdatel'stvo "Nauka", 1987, 277-299]

Струве, Глеб. Русская литература в изгнании. Изд. 3-е, испр. и дополн: ПарижМосква: YMCA-Press-Русский путь, 1996.

[Struve, Gleb. Russkaîa literatura v izgnanii. Izd. 3-e, ispr. i dopoln: Parizh-Moskva: YMCA-Press-Russkiĩ put', 1996]

Флакер, Александар. „"Нолит" и рецепција руске совјетске књижевности у Југославији“. Књижевна реч, Београд, 10. 03 1979, 9.

[Flaker, Aleksandar. ,"Nolit" i recepcija ruske sovjetske književnosti u Jugoslaviji“. Književna reč, Beograd, 10. 03 1979, 9]

\section{Извори}

Аноним. Савремени руски писци. Правда, Београд 31.01.1936,18.

[Anonim. Savremeni ruski pisci. Pravda, Beograd 31.01.1936,18]

Аноним. Предавања: “Лопов”, роман Леонида Леонова. Политика, Београд 16.12.1939,17. 
[Anonim. Predavanja: "Lopov", roman Leonida Leonova. Politika, Beograd 16.12.1939,17]

Аноним. Ремек-дела светске књижевности: Леонид Леонов. Лопов. Правда, Београд 11.03.1939a, 5 .

[Anonim. Remek-dela svetske književnosti: Leonid Leonov. Lopov. Pravda, Beograd 11.03.1939a, 5]

Аноним. Најоригиналније дело савремене светске књижевности, Лопов. Политика, Београд 23.04.1939, 29.

[Anonim. Najoriginalnije delo savremene svetske književnosti, Lopov. Politika, Beograd 23.04.1939, 29]

Аратов, Б. Совјетски часописи у 1928. години. Руски архив, Београд 1928, књ. 2, $114-115$.

[Aratov, B. Sovjetski časopisi u 1928. godini. Ruski arhiv, Beograd 1928, knj. 2, 114 115]

Благојевић, Десимир. Нова књижевна Русија, у књизи г. Слонима „Портрети савремених руских писаца“. Правда, Београд, 22.11.1930, 5.

[Blagojević, Desimir. Nova književna Rusija, u knjizi g. Slonima „Portreti savremenih ruskih pisaca“. Pravda, Beograd, 22.11.1930, 5]

Голенишчев-Кутузов, Илија. Две књиге о савременој књижевности у Русији. Српски књижевни гласник, Београд 1935, бр. 4, 302-303.

[Goleniščev-Kutuzov, Ilija. Dve knjige o savremenoj književnosti u Rusiji. Srpski književni glasnik, Beograd 1935, br. 4, 302-303]

Голенишчев-Кутузов, Илија. Послератна руска књижевност. Нова смена, Београд 1938, св.1, 26-30.

[Goleniščev-Kutuzov, Ilija. Posleratna ruska književnost. Nova smena, Beograd 1938, sv.1, 26-30]

Глуздовски, В. Савремена руска књижевност: совјетски књижевници побеђују совјетску власт. Време, Београд 10.10.1934, 6.

[Gluzdovski, V. Savremena ruska književnost: sovjetski književnici pobeđuju sovjetsku vlast. Vreme, Beograd 10.10.1934, 6]

Захаров, Евгеније. Шта захтевају бољшевици од књижевности? Правда, Београд, 23.08.1930, 4 .

[Zaharov, Evgenije. Šta zahtevaju boljševici od književnosti? Pravda, Beograd, 23.08.1930, 4]

Захаров, Евгеније. Руска књижевност у 1930. години. Летопис Матице српске, Нови Сад, 1931, св. 1,2, 96, 106.

[Zaharov, Evgenije. Ruska književnost u 1930. godini. Letopis Matice srpske, Novi Sad, 1931, sv. 1, 2, 96, 106]

Захаров, Евгеније. О данашњим руским писцима. Књижевна Крајина, Бања Лука 1931a, бp. 3, 106-108.

[ Zaharov, Evgenije. O današnjim ruskim piscima. Književna Krajina, Banja Luka 1931a, br. 3, 106-108]

Захаров, Евгеније. Шта је ново у руској књижевности. Правда, Београд, 6. - 9. јануар 1931б, бр. 6-9, 31.

[Zaharov, Evgenije. Šta je novo u ruskoj književnosti. Pravda, Beograd, 6. - 9. januar 1931b, br. 6-9, 31] 
Захаров, Евгеније. Фјодор Глатков и његов „Цемент“. Правда, Београд, 17.01.1931в, бр. 17,6 .

[Zaharov, Evgenije. Fjodor Glatkov i njegov „Cement“. Pravda, Beograd, 17.01.1931v, br. 17,6$]$

Захаров, Евгеније. Роман Јурија Тињанова. Правда, Београд, 31.01.1931г, бр. 31, 6.

[Zaharov, Evgenije. Fjodor Glatkov i njegov „Cement“. Pravda, Beograd, 17.01.1931v, br. 17,6$]$

Захаров, Евгеније. Анкета о најбољем делу данашње руске књижевности. Правда, Београд, 19.04.1931д, бр. 109, 17.

[Zaharov, Evgenije. Anketa o najboljem delu današnje ruske književnosti. Pravda, Beograd, 19.04.1931d, br. 109, 17]

Захаров, Евгеније. „Бројеви“. Правда, Београд 30. јули 1932, 7.

[Zaharov, Evgenije. „Brojevi“. Pravda, Beograd 30. juli 1932, 7]

Захаров, Евгеније. Н. Тихонов о недаћама совјетске књижевности. Правда, Београд, 8.07.1933, бр. 10298, 8.

[Zaharov, Evgenije. N. Tihonov o nedaćama sovjetske književnosti. Pravda, Beograd, 8.07.1933, br. 10298, 8]

Захаров, Евгеније. Лав Толстој и Максим Горки најчитанији су писци у совјетској Русији. Правда, Београд, 7.07.1934, бр. 10658,10.

[Zaharov, Evgenije. Lav Tolstoj i Maksim Gorki najčitaniji su pisci u sovjetskoj Rusiji. Pravda, Beograd, 7.07.1934, br. 10658,10]

Ј[елачић], Алексеј. Скутаревски. Роман. Изд. „Совјетска књижевност“ Москва. Српски књижевни гласник, Београд 1935, бр.1, 77.

[J[elačić], Aleksej. Skutarevski. Roman. Izd. „Sovjetska književnost“ Moskva. Srpski književni glasnik, Beograd 1935, br.1, 77]

Јелачић, Алексеј. Леонов Леонов, Скутаревский. Изд. Совјетска литература, Москва. Руски архив, Београд 1935, књ. 34-35, 203-206.

[Jelačić, Aleksej. Leonov Leonov, Skutarevskij. Izd. Sovjetska literatura, Moskva. Ruski arhiv, Beograd 1935, knj. 34-35, 203-206]

Мељникова-Папоушкова, Надежда. Стара и нова руска интелигенција. Руски архив, Београд 1928, књ. 2, 114-115.

[Melnikova-Papoushkova, Nadezhda. Stara i nova ruska inteligentsija. Ruski arkhiv, Beograd 1928, knj. 2, 114-115]

Митропан, Петар. Наследник Достојевског - Леонид Леонов. Нова Европа, Загреб 1929, бр. 5, 155-160. Прештампано [В:] Руски писци: скице из живота и делатности. Скопље 1934.

[Mitropan, Petar. Naslednik Dostojevskog - Leonid Leonov. Nova Evropa, Zagreb 1929, br. 5, 155-160. Reprinted [In:] Ruski pistsi: skitse iz zhivota i delatnosti. Skople 1934]

Петровић, Светислав. Нова руска литература. Српски књижевни гласник, Београд, 1926, бр. 8, 608-611.

[Petrovich, Svetislav. Nova ruska literatura. Srpski knjizhevni glasnik, Beograd, 1926, br. 8, 608-611]

Ракитина, Јулија. [Интервју] Руско позориште пред новом сезоном.Политика, Београд, октобар 1934, 6.

[Rakitina, Julija. [Intervju] Rusko pozorishte pred novom sezonom.Politika, Beograd, oktobar 1934, 6] 
Слоним, Марк. Руска књижевност за време револуције. Српски књижевни гласник, Београд, 1927, бр. 7, 498-509.

[Slonim, Mark. Ruska knjizhevnost za vreme revolutsije. Srpski knjizhevni glasnik, Beograd, 1927, br. 7, 498-509]

Слоним, Марк. Струје савремене руске литературе. Руски архив, Београд, 1928, бр. 2, 140-159.

[Slonim, Mark. Struje savremene ruske literature. Ruski arkhiv, Beograd, 1928, br. 2, 140-159]

Слоним, Марк. Портрети савремених Руских писаца: Леонид Леонов. Руски архив, Београд, 1929, књ. 5-6, 162-170.

[Slonim, Mark. Portreti savremenih Ruskih pisatsa: Leonid Leonov. Ruski arkhiv, Beograd, 1929, knj. 5-6, 162-170]

Слоним, Марк. Нова дела совјетске књижевности. Руски архив, Београд, 1930, бр. 10-11, 171-178.

[Slonim, Mark. Nova dela sovjetske kњizhevnosti. Ruski arkhiv, Beograd, 1930, br. 10$11,171-178]$

Слоним, Марк. Шта се дешава у совјетској литератури. Руски архив, Београд 1933, бр. 22-23, 92-95.

[Slonim, Mark. Shta se deshava u sovjetskoj literaturi. Ruski arkhiv, Beograd 1933, br. 22-23, 92-95]

Сосински, Бронислав. Леонид Леонов: необичне приче о сељацима. Руски архив, Београд 1929, књ. 3, 160-163.

[Sosinski, Bronislav. Leonid Leonov: neobichne priche o seljatsima. Ruski arkhiv, Beograd 1929, knj. 3, 160-163]

Струве, Глеб. Књижевност у савременој Русији. Српски књижевни гласник, Београд 1935, бр. 8, 624, 625.

[Struve, Gleb. Knjizhevnost u savremenoj Rusiji. Srpski knjizhevni glasnik, Beograd 1935 , br. 8, 624, 625]

Aleksander, Irina. Ruska književnost posle revolucije. Vijenac, Zagreb 1928, br. 7, 8, 339-340.

Rimarić-Volinski, Konstantin. Četiri pisca: Zoščenko - Erenburg - Pilnjak - Leonov. Evropa i Rusija - selo i grad. Hrvatska revija, Zagreb 1932, br. 4, 77-85.

Roščin, Nikolaj. Nekoliko riječi o današnjoj ruskoj književnosti. Vijenac, Zagreb, 1924, br. 19-20, 558 .

Fedorov, Nikolaj. Putovi stvaranja nove ruske književnosti. Hrvatska smotra, Zagreb 1940 , br. 7, 8, 356, 358-359. 
Богдан Косанович

\section{ТВОРЧЕСТВО ЛЕОНИДА ЛЕОНОВА В КРИТИКЕ РУССКОЙ ЭМИГРАЦИИ В КОРОЛЕВСТВЕ СХС/ЮГОСЛАВИИ}

\section{Резюме}

Отмечая сто двадцатилетие со дня рождения Л. М. Леонова, в этом исследовании мы обращаемся к эмигрантской рецепции его произведений в Югославии - в период между двумя мировыми войнами.

Собранный нами материал (37 критических откликов) показывает, что - прежде всего благодаря эмигрантской печати - в интересующий нас период Леонов был самым популярным советским писателем в Югославии. Открытие Леонова подтолкнуло сербских и хорватских критиков писать о нем, переводить его произведения.

Ключевые слова: Леонид Леонов, русская эмиграция, рецепция. 